\title{
Evidence of Leishmania spp. antibodies and DNA in dogs in the Middle Black Sea Region of Turkey
}

\author{
Cenk Soner BOLUKBAS ${ }^{1}$, Gokmen Zafer PEKMEZCI ${ }^{2}$, Ali Tumay GURLER ${ }^{1}$, Didem PEKMEZCI ${ }^{3}$, \\ Murat GUZEL $^{3}$, Murat HOKELEK ${ }^{4}$, Mustafa ACICI ${ }^{1}$, Sinasi UMUR ${ }^{1}$
}

\begin{abstract}
Ondokuz Mayss University, Faculty of Veterinary Medicine, ${ }^{1}$ Department of Parasitology, ${ }^{2}$ Department of Preclinical Science, ${ }^{3}$ Department of Internal Medicine, Samsun; İstanbul University, Cerrahpaşa Faculty of Medicine, ${ }^{4}$ Department of Microbiology, İstanbul, Turkey.
\end{abstract}

\begin{abstract}
Summary: The World Health Organization considers leishmaniasis to be one of the most important zoonotic diseases with approximately 350 million people in 98 countries at risk of contracting the disease. The leishmaniasis also remains a severe public health problem in Turkey. It is important to evaluate the prevalence of Canine leishmaniasis (CanL) for designing control policies. In the present study, we report for the first time the occurrence of Leishmania infection in dogs living in the Middle Black Sea Region of Turkey. For the diagnosis of the infection parasitological (direct microscopic examination of lymph nodes), serological (ELISA) and molecular (kDNA-PCR) methods were performed using blood samples obtained from 240 dogs. Sand flies were also collected using CDC miniature light traps from the same locations for testing Leishmania presence by kDNA-PCR. Only one $(0.41 \%)$ dog out of 240 was found to be positive by both tests. Amastigotes of Leishmania spp. were detected in the same animal lymph node aspirate sample. A total of 18 sand flies were collected and no Leishmania was detected Phlebotomus spp. sample pool. Our results showed that CanL could have public health implications and future screening studies are needed in this region of Turkey.

Keywords: Canine leishmaniasis, Dog, ELISA, Middle Black Sea Region, PCR, Turkey.
\end{abstract}

\section{Orta Karadeniz Bölgesi'nde köpeklerde Leishmania spp. antikor ve DNA'sının kanıtı}

Özet: Dünya Sağlık Örgütü 98 ülkede, yaklaşık 350 milyon kişinin hastalığa yakalanma riski taşıdığı leishmaniasisi en önemli zoonozlardan birisi olarak görmektedir. Leishmaniasis aynı zamanda Türkiye'de de ciddi bir halk sağlığı problemidir. Hastalı̆̆ın kontrol politikalarını oluşturabilmek için köpek leishmaniasisin yaygınlığının bilinmesi büyük önem taşımaktadır. Bu çalışma ile Orta Karadeniz Bölgesi'nde köpeklerde Leishmania enfeksiyonu ilk kez bildirildi. Enfeksiyonun tanısı için 240 köpekten alınan örnekler parazitolojik (lenf aspiratı), serolojik (ELISA) ve moleküler (kDNA-PCR) yöntemler kullanılarak incelendi. Aynı bölgelerden CDC (Centers for Disease Control) minyatür ışı tuzakları kullanılarak kum sinekleri yakalandı ve kDNA-PCR ile Leishmania varlığı yönünden incelendi. İncelenen 240 kan örneğinin sadece birinde (\% 0.41) Leishmania cinsine karşı antikor ve Leishmania kDNA'sı tespit edildi. Aynı köpeğin lenf aspiratında Leishmania spp. amastigotlarına rastlandı. Bununla birlikte Phlebotomus spp. örnek havuzunda Leishmania kDNA'sı saptanmadı. Sonuçlar göz önüne alındığında köpek leishmaniasisin halk sağlığına etkileri olabileceği ve bu bölgede tarama çalışmalarına devam edilmesine ihtiyaç olduğu düşünülmüştür.

Anahtar sözcükler: ELISA, Köpek, Köpek leishmaniasis, Orta Karadeniz Bölgesi, PCR, Türkiye.

\section{Introduction}

Canine leishmaniasis (CanL) is caused by Leishmania infantum, and is a major potentially fatal zoonotic infection in some regions of Europe, Africa, Asia and America continents. The domestic dog is the main reservoir of human infection, and phlebotomine sand flies are the biological vectors of this protozoal disease (3). Infection with L. infantum is considerably more prevalent than clinical disease, and infected dogs with no signs of disease might, potentially, transmit infection. Diagnosis of asymptomatic infection by serology is insufficient and PCR markedly increases its sensitivity (6). A specific PCR-based method is appealing as it is rapid, sensitive, and specific, avoiding culturing of parasites, thus being suitable for leishmaniasis surveillance programs that require efficient laboratorial response for rapid and effective actions (5).

Canine leishmaniasis has a higher prevalence rates than human infection in all regions of Turkey (9). CanL was first detected in the early 1950's in Turkey. Recently, the epidemiological studies were carried out different provinces and the prevalence ratios were found

\footnotetext{
* This study was supported by The Scientific Research Council of the Ondokuz Mayis University, Samsun, Turkey (Project number, PYO.VET.1901.10.004)
} 
between $1.45 \%$ and $27.5 \%$ in Turkey. The overall prevalence of CanL was detected as $11.32 \%$ in Turkey (9, 10, 11, 14). Turkey represents a crossroad between Europe and Asia, and shows different ecological and climatic conditions, which are important in the epidemiology of leishmaniasis (8).

Canine leishmaniasis is endemic in South-Eastern and Mediterranean Regions of Turkey (8), resulting in important public health problem. It is essential to evaluate the prevalence of CanL infection for designing control policies. Although CanL has also been reported in the Marmara, Aegean, Mediterranean and SouthEastern regions of Turkey, no data has been reported from northern Turkey. The aim of this study was to understand the status of CanL in northern Turkey using serological and molecular methods.

\section{Materials and Methods}

Animals and sampling: Blood samples were collected from 210 stray dogs captured in Animal Shelter of Metropolitan Municipality located in Central Samsun and Amasya, Ordu, Sinop, Tokat between 2010 and 2013 (Fig 1). Thirty privately owned-dogs that had been admitted to the Animal Hospital of Veterinary Faculty, Ondokuz Mayis University, were also included the study and screened for the presence of Leishmania spp. Three milliliter ( $\mathrm{ml}$ ) blood samples were taken from the cephalic vein and put into EDTA containing tubes and five $\mathrm{ml}$ of the blood sample was taken for separating sera for the detection of specific antibodies to Leishmania. For parasitological examinations, popliteal lymph node aspirate samples were prepared from each dog. Samples were transported to the laboratory in coolers containing ice packs. Sandflies were collected using CDC miniature light traps in and around domestic animal shelters and from the locations in different cities where animals were captured. The traps were placed approximately 1.5 meters above the ground level and set in mid to late afternoon for the collection and kept until the following morning. The samples were then placed in plastic vials and shipped on dry ice to our laboratory and identified. The protocol for sampling had been reviewed and approved by the Ethical Review Committee of the Ondokuz Mayis University (No: HAYDEK/109).

Parasitological examination: Lymph smears were fixed with methanol, stained with Giemsa, and examined microscopically for the presence of amastigotes.

ELISA: Serum samples were tested for IgG-class antibodies against Leishmania spp. by an enzyme-linked immunosorbent assay (ELISA) kits (Leishmania Canine IgG, Novatec Immundiagnostica Gmbh, Germany). Serum samples were processed according to manufacturer`s instructions. The results were measured at $450 \mathrm{~nm}$ with an ELISA reader (Plate Reader, DAS, Italy). The samples with an OD value higher than the 20 $\%$ of cut-off measurement were evaluated as positive.

DNA extraction and PCR amplification: The DNA was extracted from blood samples and Phlebotomus pool using blood \& tissue extraction kit (DNeasy, Qiagen, Germany) according to manufacturer's instruction. DNA content was determined using a NanoDrop 2000 spectrophotometer (Thermo Scientific) at $260 \mathrm{~nm}$. The presence of Leishmania DNA in samples was detected by PCR using genus-specific primer 13a (5'GTGGGGGAGGGGCGTTCT-3') and 13b (5'ATTTTACACCAACCCCCAGTT-3') (17) according to

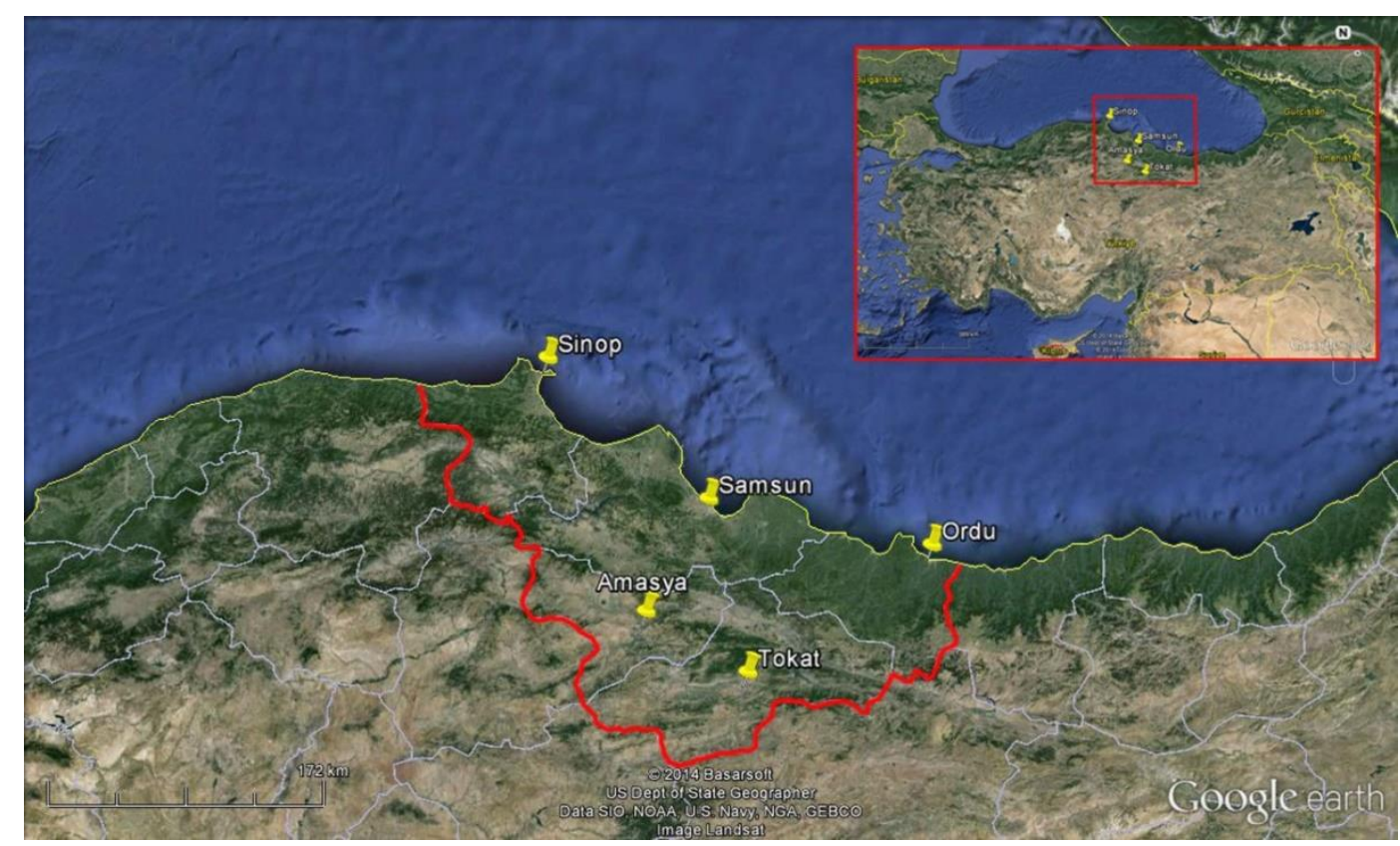

Figure 1. The map of northern Turkey showing the location of the study sites. Şekil 1. Çalışma bölgelerini gösteren kuzey Türkiye haritası. 
the protocol described by Reale et al. (16). These primers were synthesized by AlphaDNA (Montreal, Canada). PCR amplification was carried out in $50 \mu$ reactions containing (final concentrations) $2 \mathrm{mM} \mathrm{MgCl} 2(25 \mathrm{mM})$ (Thermo), $10 \mathrm{mM}$ Tris- $\mathrm{HCl}$ - $50 \mathrm{mM} \mathrm{KCl}$ (Thermo), 250 mM dNTPmix (10 mM) (Sigma), 20 pmol each primer, $10 \mu 1$ template DNA solution and $2.5 \mathrm{U}$ Taq polymerase $(5 \mathrm{U} / \mu \mathrm{l})$ (Thermo). Reactions were performed in a thermal cycler (Thermo Pxe 0.2, USA). The conditions were set as follows; denaturation at $95{ }^{\circ} \mathrm{C}$ for $1 \mathrm{~min}$., 30 cycles consisting of denaturation at $94{ }^{\circ} \mathrm{C}$ for $1 \mathrm{~min}$., annealing at $60^{\circ} \mathrm{C}$ for $1 \mathrm{~min}$., and extension at $72{ }^{\circ} \mathrm{C}$ for $1 \mathrm{~min}$. A $5 \mathrm{~min}$. final extension period at $72{ }^{\circ} \mathrm{C}$ was added after 30 cycles. PCR outcomes were analyzed by electrophoresis in a $2 \%$ agarose gel and the results were photographed with imaging system (Minibis Pro, DNR, Israel).

\section{Results}

Leishmania spp. amastigotes, antibodies and kDNA were detected positively only one dog which brought to the Animal Hospital of Veterinary Faculty (Samsun) from Sinop provinces. Amastigotes of Leishmania spp.

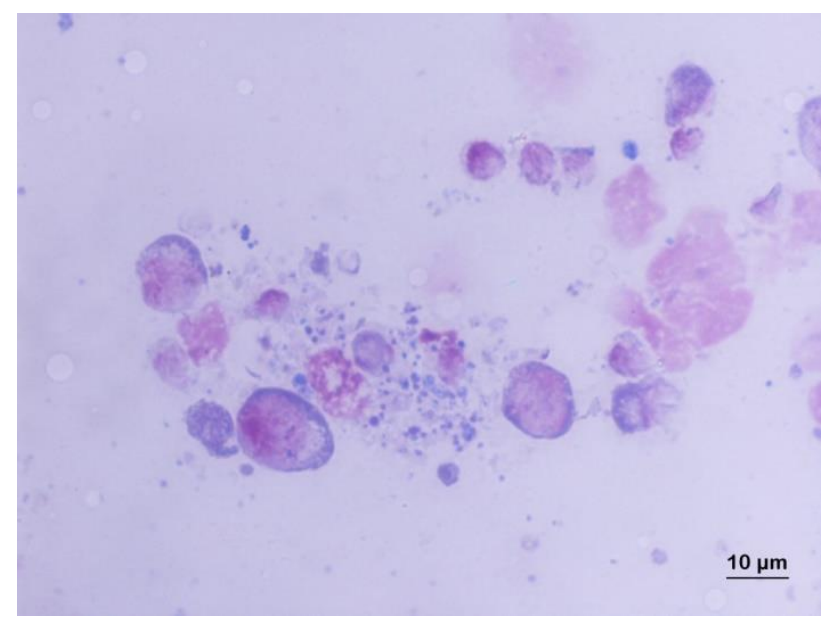

Figure 2. Giemsa stain smear showing the amastigote forms of Leishmania spp.

Şekil 2. Leishmania spp.nin amastigot formlarını gösteren Giemsa boyalı smear. were detected in one $(0.41 \%)$ of 240 lymph node aspirate samples for microscopic examination (Fig 2). The antibodies against Leishmania spp. was detected in the one $(0.41 \%)$ of 240 sera samples by ELISA. Similarly, Leishmania kDNA was detected one $(0.41 \%)$ of the 240 analyzed blood samples by PCR. The results of samples are given in Table 1 .

A total of 18 sand flies (one pool) were trapped using CDC miniature light traps in the present study. Sand flies were found only in Sinop province. All sand flies were morphologically identified as Phlebotomus spp. No Leishmania kDNA was detected in the sample pool.

\section{Discussion and Conclusion}

Despite the existence of Phlebotomus spp. in this area together with the earlier detection of positive human cases (19); there has been no report about the occurrence of CanL in the Middle Black Sea Region, Turkey. For this reason, the purpose of this study is to provide epidemiological data about the occurrence of leishmaniasis among dogs in northern Turkey. In this study, as diagnostic mass-screening tools, ELISA and PCR were used to determine the regional occurrence of CanL. This is the first study on the investigation of the prevalence of CanL in the Middle Black Sea Region.

Seroepidemiological studies mainly on CanL were previously carried out in different regions of Turkey. In the Aegean Region, seroprevalence of CanL were found between $5.3 \%(26 / 490)$ and $20.71 \%$ (29/140) (2, 10, 11 , 12, 14). In Central Anatolia, the seroprevalence of CanL was reported between $2.58 \%(3 / 116)$ and $13.74 \%$ $(18 / 131)(1,4)$. In the Western Black Sea Region, the seroprevalence of CanL was reported as $20 \%$ (5/25) (13). Within the present study, carried out in the Middle Black Sea Region, CanL was sporadically detected as $0.41 \%$ $(1 / 240)$ by the use of the serological test ELISA.

Over the years, a number of different PCR assays have been developed for the detection of Leishmania DNA in a variety of clinical samples such as skin biopsies and smears, bone marrow and lymph node

Table 1. Leishmania spp. infection diagnosed by lymph node smears, ELISA and PCR in dogs in the Middle Black Sea Region of Turkey

Tablo 1. Orta Karadeniz Bölgesi'nde köpeklerde lenf nodu sürme preparatı, ELISA ve PCR ile teşhisi yapılan Leishmania spp. enfeksiyonu

\begin{tabular}{|c|c|c|c|c|}
\hline \multirow[t]{2}{*}{ Locations } & \multirow[t]{2}{*}{ Number of dogs examined } & \multicolumn{3}{|c|}{ Leishmania spp. } \\
\hline & & Microscopy & ELISA & PCR \\
\hline Samsun (Animal Shelter) & 170 & - & - & - \\
\hline Amasya & 10 & - & - & - \\
\hline Ordu & 10 & - & - & - \\
\hline Sinop & 10 & - & - & - \\
\hline Tokat & 10 & - & - & - \\
\hline Animal Hospital of Veterinary Faculty (Samsun) & 30 & 1 & 1 & 1 \\
\hline Total & 240 & $1(0.41 \%)$ & $1(0.41 \%)$ & $1(0.41 \%)$ \\
\hline
\end{tabular}


aspirates and peripheral blood. Recently, molecular methods have been used increasingly to identify Leishmania infection, as a sensitive and effective tool to facilitate strategic planning for the control of leishmaniasis (18) in epidemiological studies. CanL and VL are still significant public health problems in Turkey (8).

In the present study, 240 DNA samples were examined by $13 \mathrm{a}-13 \mathrm{~b}$ primers, and the PCR products were considered positive when a band of correct size kDNA of $\sim 120$ bp was observed for Leishmania isolates (7, 15, 16, 17). This is the first report documenting the existence of Leishmania spp. kDNA in naturally infected dogs from the Middle Black Sea Region of Turkey. In the present study, the dogs that originated in the places without Phlebotomus spp. were all found to be Leishmania spp. antibody and kDNA free. Out off the 240 dogs tested, only one dog, which was brought to the Animal Hospital of Veterinary Faculty (Samsun) from Sinop province, was found to be Leishmania spp. antibodies and kDNA positive. Phlebotomus spp. were also found in the Sinop province. The low sandfly population in this area could easily explain the low prevalence of Leishmania spp. in the dogs that came from Sinop province. Moreover, the low sandfly population could be resulted from the differences of the local climate conditions such as the temperature and the humidity characteristics of the region.

In conclusion, the current investigation of CanL provided the first epidemiological data about a public health threatening disease, from the Middle Black Sea Region. CanL was sporadically detected in only one symptomatic dog from northern Turkey. Thus, the occurrence of one positive case indicates a need for future screening studies in this region of Turkey.

\section{Acknowledgements}

We thank to the Department of Bioengineering, Y1ldı Technical University for sending the L. infantum positive control.

\section{References}

1. Aslantaş Ö, Özdemir V, Kılıç S, et al (2005): Seroepidemiology of leptospirosis, toxoplasmosis, and leishmaniosis among dogs in Ankara, Turkey. Vet Parasitol, 129, 187-191.

2. Atasoy A, Paşa S, Özensoy Toz S, et al (2010): Seroprevalence of canine visceral leishmaniasis around the Aegean cost of Turkey. Kafkas Univ Vet Fak Derg, 16, $1-6$.

3. Baneth G, Koutinas AF, Solano-Gallego L, et al (2008): Canine leishmaniosis - new concepts and insights on an expanding zoonosis: part one. Trends Parasitol, 24, 324330.

4. Ertabaklar H, Özensoy Toz S, Taylan Özkan A, et al (2005): Serological and entomological survey in a zoonotic visceral leishmaniasis focus of North Central Anatolia, Turkey: Corum province. Acta Trop, 93, 239246.

5. Gomes AHS, Ferreira IMR, Lima MLSR, et al (2007): PCR identification of Leishmania in diagnosis and control of canine leishmaniasis. Vet Parasitol, 144, 234-241.

6. Miró G, Cardoso L, Pennisi MG, et al (2008): Canine leishmaniosis - new concepts and insights on an expanding zoonosis: part two. Trends Parasitol, 24, 371-377.

7. Motazedian H, Karamian M, Noyes HA, et al (2002): DNA extraction and amplification of Leishmania from archived, Giemsa-stained slides, for the diagnosis of cutaneous leishmaniasis by PCR. Ann Trop Med Parasit, 96, 31-34.

8. Ok ÜZ, Balcığlu İC, Özkan AT, et al (2002): Leishmaniasis in Turkey. Acta Tropica, 84, 43-48.

9. Özbel Y (2013): The infections transmitted by Sand flies in Turkey. Ankara Univ Vet Fak Derg, 60, 225-228.

10. Özbel Y, Oskam L, Özensoy S, et al (2000): A survey on canine leishmaniasis in western Turkey by parasite, DNA and antibody detection assays. Acta Tropica, 74, 1-6.

11. Özensoy Toz S, Ertabaklar H, Özbel Y, et al (2005): Seroprevalance of canine visceral leishmaniasis in Kusadasi, Turkey. Turkish J Vet Anim Sci, 29, 23-26.

12. Özensoy Toz S, Özbel Y, Ertabaklar H, et al (2005): Comparisons of clinical findings and serological data in the diagnosis of canine leishmaniosis. Turk J Vet Anim Sci, 29, 269-273.

13. Özensoy Toz S, Özbel Y, Turgay N, et al (1998): Serodiagnosis and epidemiology of visceral leishmaniasis in Turkey. Am J Trop Med Hyg, 59, 363-369.

14. Özensoy Toz S, Şakru N, Ertabaklar H, et al (2009): Serological and entomological survey of zoonotic visceral leishmaniasis in Denizli province, Aegean Region, Turkey. New Microbiologica, 32, 93-100.

15. Özerdem D, Eroğlu F, Genç A, et al (2009): Comparison of microscopic examination, rK39, and PCR for visceral leishmaniasis diagnosis in Turkey. Parasitol Res, 106, $197-$ 200.

16. Reale S, Maxia L, Vitale F, et al (1999): Detection of Leishmania infantum in dogs by PCR with lymph node aspirates and blood. J Clin Microbiol, 37, 2931-2935.

17. Rodgers MR, Popper SJ, Wirth DF (1990): Amplification of kinetoplast DNA as a tool in the detection and diagnosis of Leishmania. Exp Parasitol, 71, 267-275.

18. Schallig HDFH, Oskam L (2002): Molecular biological applications in the diagnosis and control of leishmaniasis and parasite identification. Trop Med Int Health, 7, 641651.

19. Totan M, Hökelek M, Çetinkaya MC (2003): Five pneumonia cases associated with visceral leishmaniasis in Turkey. Intern Pediatr, 18, 185-187.

Geliş tarihi: 21.10.2014 / Kabul tarihi: 21.04.2015
Address for correspondence:
Dr. Cenk Soner Bölükbaș
Ondokuz Mayls University,
Faculty of Veterinary Medicine,
Department of Parasitology, Samsun 55139, Turkey
e-mail:cbolukbas@omu.edu.tr 